\title{
Immobilization of $\mathrm{Fe}(\mathrm{III})$ complexes of pyridazine derivatives prepared from biosorbents supported on zeolites
}

\author{
Hugo Figueiredo ${ }^{\text {b, Bruna Silva }}{ }^{\mathrm{b}}$, M. Manuela M. Raposo ${ }^{\mathrm{a}}$, António M. Fonseca ${ }^{\mathrm{a}}$, \\ Isabel C. Neves ${ }^{a, *}$, Cristina Quintelas ${ }^{b}$, Teresa Tavares ${ }^{b, *}$ \\ a Departamento de Química, Centro de Química, Universidade do Minho, Campus de Gualtar, 4710-057 Braga, Portugal \\ b IBB - Instituto de Biotecnologia e Bioengenharia, Centro de Engenharia Biológica, Universidade do Minho, Campus de Gualtar, $4710-057$ Braga, Portugal
}

Received 8 September 2006; received in revised form 12 April 2007; accepted 19 April 2007

Available online 3 May 2007

\begin{abstract}
Immobilization of $\mathrm{Fe}(\mathrm{III})$ complexes of pyridazine derivatives was achieved in $\mathrm{NaY}$ zeolite, loaded with iron through the action of a robust biosorption mediator consisting of a bacterial biofilm, Arthrobacter viscosus, supported on the zeolite. The objective of this study is the preparation and characterization of new catalytic materials to be used in oxidation reactions under mild conditions. The biosorption of $\mathrm{Fe}(\mathrm{III})$ ions was performed starting from aqueous solutions with low concentrations of iron and the highest values of biosorption efficiency for $\mathrm{Fe}(\mathrm{III})$ were reached at the beginning of the contact period with the sorbents. The $\mathrm{Fe}(\mathrm{III})$ biosorption process was compared with the one of $\mathrm{Cr}(\mathrm{III})$ under the same experimental conditions, as this latter case has been well characterized. The sample used in the immobilization of $\mathrm{Fe}(\mathrm{III})$ complexes of pyridazine derivatives was prepared from an aqueous solution of $100.0 \mathrm{mg}_{\mathrm{Fe}} / \mathrm{L}$, without the competing effect of other metals. Fe(III) is retained in the zeolite by ion exchange and coordination with two different pyridazine derivative ligands, 3-ethoxy-6-chloropyridazine (A) and 3-piperidino-6-chloropyridazine (B). The resulting materials were fully characterized by different spectroscopic methods (EPR, FTIR and UV-vis), chemical analysis (CA), surface analysis (XRD and SEM) and thermogravimetric (TGA) analysis and the results indicated that the $\mathrm{Fe}(\mathrm{III})$ complexes of pyridazine derivatives were effectively immobilized in $\mathrm{NaY}$ inside the supercages, without any modifications of the morphology and structure of the zeolite. The EPR spectra of the Fe(III) complexes in $Y$ zeolite show signals at $g=4.3$ and 2.3, attributed to $\mathrm{Fe}(\mathrm{III})$ species coordinated to pyridazine derivative ligands.
\end{abstract}

(c) 2007 Elsevier Inc. All rights reserved.

Keywords: NaY; Arthrobacter viscosus; Biosorbents; Fe(III); Pyridazine derivative ligand; Immobilization

\section{Introduction}

Concern regarding sustainable development is responsible for the concentration of research efforts on the effects of toxic metals on the environment, since they ultimately reach and accumulate in animal and human tissues. In accordance with water standard procedures used in most countries, heavy metal ions in wastewater must be controlled and reduced to below fixed reference values. Waste-

\footnotetext{
* Corresponding authors. Tel.: +351 253604057; fax: +351 253678983 (I.C. Neves).

E-mail addresses: ineves@quimica.uminho.pt (I.C. Neves), ttavares@deb.uminho.pt (T. Tavares).
}

water treatment, including the removal of heavy metal ions, generally depends on the size and type of the emission plant, as well as on the characteristics and flow rate of wastewater. Numerous processes exist for removing heavy metal ions including chemical precipitation, chemical oxidation and reduction, ion exchange, membrane filtration and carbon adsorption [1]. These processes however have significant disadvantages such as incomplete metal removal, high reagent or energy requirements, generation of toxic sludge or other waste products and are generally very expensive when the contaminant concentrations are in the range $10.0-100.0 \mathrm{mg} / \mathrm{L}$ [2]. Cost effective alternative technologies or sorbents for treatment of metal-contaminated waste streams are needed. In this respect, zeolites 
have a great potential for removing heavy metal from industrial wastewater. The peculiar adsorptive properties of zeolites result from the ability of positively charged exchangeable ions, which are located inside the threedimensional pore structure of the solid, to balance the negative charge on the framework $\mathrm{Al}$ atoms. These atoms can be replaced by heavy metals [3].

Biosorption is the accumulation of metals by biological materials without active uptake and can be considered to be a collective term for a number of passive accumulation processes which may include ion exchange, coordination, complexation, chelation, adsorption and micro-precipitation [4]. Other authors [5] have defined biosorption as the ability of biological materials to accumulate heavy metals from waste streams by either metabolical mediation or by purely physico-chemical uptake pathways.

The biosorption of heavy metals by microorganisms is a promising process with potential for industrial application, suitable for natural environments and of low cost. Arthrobacter viscosus is a good exopolysaccharide producer, an aspect which would permit prediction of good adhesion to the support and metal ion entrapment [6] through capture by the polysaccharide net developed by the biofilm. The new systems herein presented combine the biosorption properties of the microorganism with the metal ion immobilization ability of the zeolite due to its ion exchange properties and shape selectivity. The role of the biofilm mediator is the enhancement of an alternative, efficient and quite competitive path for metal ion immobilization.

During the last two decades the preparation and catalytic activity of transition metal complexes encapsulated in micro- and meso-structures have been extensively investigated due to their industrial significance [7-12]. Encapsulation of transition metal complexes that may act as homogeneous catalysts, within the structure of zeolites provides a way to greatly simplify their separation from the reaction mixture and to improve the recycling of expensive catalysts. These heterogeneous systems provide information at the molecular level about the interactions between the zeolite and their guest complexes [13-18].

The present work associates biosorption studies to the immobilization of transition metal complexes in zeolites for applications in heterogeneous catalysis in mild conditions. Presently, we are interested in the study of the immobilization of iron metal complexes on $\mathrm{Y}$ zeolite for oxidation reactions. The iron metal complexes imitate the role of the active site and the zeolite replaces the protein moiety of metalloenzymes [19]. The synthesis of $\mathrm{Fe}(\mathrm{III})$ complexes of pyridazine derivatives immobilized in supercages of $\mathrm{Y}$ zeolite was carried out by free diffusion of the pyridazine derivative ligands through the zeolite pores exchanged with the $\mathrm{Fe}$ (III) metal ion, obtained by the previous use of the biosorption process [20,21].

The ability of pyridazine to form metal complexes has led to applications in the growing area of molecular selfassembly. The pyridazine skeletons are commonly found in compounds exhibiting a wide range of biological activity
$[22,23]$. The derivatives of pyridazine could also find application as ligands in supramolecular chemistry and in metallic complexes which exhibit catalytic properties [24,25].

The present work deals with the multi-step synthesis and characterization of new heterogeneous materials, specifically $\mathrm{Fe}(\mathrm{III})$ complexes of pyridazine derivatives prepared through a robust biosorption mediator consisting of a bacterial biofilm supported on Y zeolite. The preparation procedure includes: (i) the sorption of $\mathrm{Fe}$ (III) from aqueous solutions by A. viscosus bacterium, a biosorbent supported on $\mathrm{NaY}$, in batch experiments; (ii) the synthesis of pyridazine derivative ligands, 3-ethoxy-6-chloropyridazine (A) and 3-piperidino-6-chloropyridazine (B) and (iii) the immobilization procedure of the $\mathrm{Fe}(\mathrm{III})$ complex in $\mathrm{Y}$ zeolite. The samples obtained have been fully characterized by spectroscopic methods (FTIR, EPR and UV-vis) chemical analysis (ICP-AES), X-ray power diffraction (XRD), scanning electron microscopy (SEM) and by thermogravimetric analysis (TGA). The material so prepared may be used as catalyst under mild conditions and its activity and selectivity have been described elsewhere [26]. What would be a solid residual material for many industries working with iron in solution may therefore be transformed into an active and selective catalyst, by the procedure described in this paper.

\section{Experimental section}

\subsection{Materials and reagents}

A. viscosus was obtained from the Spanish Type Culture Collection of University of Valência. Aqueous iron chloride solutions were prepared by dissolving $\mathrm{FeCl}_{3} \cdot 6 \mathrm{H}_{2} \mathrm{O}$ (Riedel) in distilled water, in concentrations up to $100.0 \mathrm{mg}_{\mathrm{Fe}} / \mathrm{L}$. Aqueous chromium chloride solutions were prepared by dissolving $\mathrm{CrCl}_{3} \cdot 6 \mathrm{H}_{2} \mathrm{O}$ (Riedel) in distilled water, in concentrations up to $100.0 \mathrm{mg}_{\mathrm{Cr}} / \mathrm{L}$. NaY zeolite $(\mathrm{Si} / \mathrm{Al}=2.88)$ was obtained from W.R. Grace (previously calcined at $500{ }^{\circ} \mathrm{C}$ during $8 \mathrm{~h}$ under a dry air stream). Chemicals for the synthesis of the pyridazine derivative ligands, 3-ethoxy-6-chloropyridazine (A) and 3-piperidino-6-chloropyridazine (B) and for the immobilization procedure were purchased from Aldrich. All the materials used were reagent grade.

\subsection{Sample preparation}

\subsubsection{Preparation of the biofilm supported on $Y$ zeolite}

All experimental work was conducted in triplicate. A. viscosus bacteria were grown for $24 \mathrm{~h}$ in $500 \mathrm{~mL}$ of the following culture medium: $10.0 \mathrm{~g} / \mathrm{L}$ glucose, $5.0 \mathrm{~g} / \mathrm{L}$ peptone, $3.0 \mathrm{~g} / \mathrm{L}$ yeast extract and $3.0 \mathrm{~g} / \mathrm{L}$ malt extract. The medium was sterilized at $120^{\circ} \mathrm{C}$ for $20 \mathrm{~min}$, cooled to room temperature, inoculated with bacteria and kept at $28^{\circ} \mathrm{C}$ for $24 \mathrm{~h}$ with moderate stirring in a incubator.

$1.0 \mathrm{~g}$ of the $\mathrm{NaY}$ zeolite was placed in an Erlenmeyer flask to which $15 \mathrm{~mL}$ of $A$. viscosus culture media above 
described were added. Finally, $150 \mathrm{~mL}$ of the different aqueous metal solutions were added: (a) $C_{\mathrm{Fe}}^{\mathrm{III}}=11.3 \mathrm{mg} / \mathrm{L}$ and $\quad C_{\mathrm{Cr}}^{\mathrm{III}}=9.3 \mathrm{mg} / \mathrm{L}, \quad$ (b) $\quad C_{\mathrm{Fe}}^{\mathrm{III}}=27.7 \mathrm{mg} / \mathrm{L} \quad$ and $C_{\mathrm{Cr}}^{\mathrm{III}}=23.7 \mathrm{mg} / \mathrm{L}$ and (c) $C_{\mathrm{Fe}}^{\mathrm{III}}=53.1 \mathrm{mg} / \mathrm{L}$ and $C_{\mathrm{Cr}}^{\mathrm{Il}}=51.4 \mathrm{mg} / \mathrm{L}$. Experiments were repeated without the zeolite for comparative purposes.

Samples for downstream processing were prepared by starting from $C_{\mathrm{Fe}}^{\mathrm{III}}=100.0 \mathrm{mg} / \mathrm{L}$, without any other metal in solution. All flasks were closed and kept at $28{ }^{\circ} \mathrm{C}$ with moderate stirring. Samples were taken $(1 \mathrm{~mL})$, centrifuged and analyzed for metals using an atomic absorbance spectrophotometer (AAS). The samples were filtered off and washed with distilled water.

\subsubsection{Immobilization of the $\mathrm{Fe}$ (III) complexes of pyridazine derivatives in $Y$ zeolite}

2.2.2.1. Step 1. Synthesis of pyridazine derivative ligands. 3Ethoxy-6-chloropyridazine ligand has been synthesized using the experimental method described in a previous publication [20]. 3-Piperidino-6-chloropyridazine ligand was prepared according the following experimental procedure: 3,6-dichloropyridazine $(6.7 \mathrm{mmol})$ was heated at reflux with piperidine $(20.1 \mathrm{mmol})$ in ethanol $(10 \mathrm{~mL})$ for $5 \mathrm{~h}$, then cooled and the solvent was removed under reduced pressure to produce an oily solid. This solid was poured into water $(100 \mathrm{~mL})$ and extracted with ethyl acetate $(3 \times 30 \mathrm{~mL})$. The organic extract was dried with $\mathrm{MgSO}_{4}$ and the solvent was evaporated under reduced pressure to give the crude product which was purified by "flash" chromatography on silica with increasing amounts of ether in petrol ether (b.p. $40-60{ }^{\circ} \mathrm{C}$ ) as eluent. The product was obtained in $89 \%$ yield as beige solid. Mp 76.9$78.0^{\circ} \mathrm{C}$; IR $v_{\max }(\mathrm{KBr}) / \mathrm{cm}^{-1} 2930,1587,1529,1481$, $1458,1439,1263,1250,1214,1172,1157,1140,1025$, $1017,1004,975,830,621 ; \delta_{\mathrm{H}}\left(300 \mathrm{MHz} ; \mathrm{CDCl}_{3}\right) / \mathrm{ppm}$ 1.59-1.80 (m, $\left.6 \mathrm{H}, \quad 3 \times \mathrm{CH}_{2}\right), \quad 3.61-3.63 \quad(\mathrm{~m}, \quad 4 \mathrm{H}$, $\left.2 \times \mathrm{NCH}_{2}\right), 6.89(\mathrm{~d}, 1 \mathrm{H}, J=9.3 \mathrm{~Hz}, 4-\mathrm{H}), 7.16(\mathrm{~d}, 1 \mathrm{H}$, $J=9.3 \mathrm{~Hz}, \quad 5-\mathrm{H}) ; \quad \delta_{\mathrm{C}}\left(75.4 \mathrm{MHz} ; \quad \mathrm{CDCl}_{3}\right) / \mathrm{ppm} \quad 24.35$, 25.22, 46.18, 115.21, 128.48, 145.86, 159.00; Anal. Calcd for $\mathrm{C}_{9} \mathrm{H}_{12} \mathrm{ClN}_{3}$ : C, 54.63; H, 6.11; N, 21.23. Found: C, 54.32; H, 6.34; N, 21.35 .

\subsubsection{Immobilization of $\mathrm{Fe}$ (III) complexes of pyridazine} derivatives. Zeolite-immobilized Fe(III) complexes of pyridazine derivatives from biosorbents supported in $\mathrm{Y}$ zeolite were prepared according the following experimental procedure: The $\mathrm{Fe}^{\mathrm{III}}-\mathrm{Y}$ sample, obtained from $100.0 \mathrm{mg}_{\mathrm{Fe}} / \mathrm{L}$ solution in biosorption assays, was previously calcined at $500{ }^{\circ} \mathrm{C}$ during $8 \mathrm{~h}$ under a dry air stream before immobilization in order to remove the organic matter of the $A$. viscosus bacterium. This heat treatment is essential to assure that the organic matter is completely burnt off and will not participate in the immobilization procedure and to allow the ion exchange between the zeolite and the residual $\mathrm{Fe}(\mathrm{III})$.

Solutions of different pyridazine ligands (3-ethoxy-6chloropyridazine $-6.30 \times 10^{-1} \mathrm{mmol}$ and 3-piperidino-6- chloropyridazine $-5.10 \times 10^{-1} \mathrm{mmol}$ ) in $100 \mathrm{~mL}$ of ether were added to $0.5 \mathrm{~g}$ of $\mathrm{Fe}^{\mathrm{III}}-\mathrm{Y}$. The resulting mixtures were refluxed for $24 \mathrm{~h}$ and the suspension was filtered off, in order to remove the excess of pyridazine ligands. The orange solid was washed with ethanol and distilled water and dried at $60{ }^{\circ} \mathrm{C}$ for $8 \mathrm{~h}$. The uncomplexed iron ions present in the zeolite were removed by exchanging with aqueous $0.01 \mathrm{M} \mathrm{NaCl}$ solution for $8 \mathrm{~h}$ at room temperature and subsequently filtered off and washed with distilled water [13]. The resulting materials were purified by Soxhlet extraction with ethanol for $6 \mathrm{~h}$. Finally, the samples were dried in an oven at $60^{\circ} \mathrm{C}$ for $12 \mathrm{~h}$. The solid samples obtained were denoted as $\left[\mathrm{Fe}^{\mathrm{III}} \mathrm{L}_{\mathrm{A}}\right]-\mathrm{Y}$ and $\left[\mathrm{Fe}^{\mathrm{III}} \mathrm{L}_{\mathrm{B}}\right]-\mathrm{Y}$ where $\mathrm{L}_{\mathrm{A}}$ represents the ligand 3-ethoxy-6-chloropyridazine and $\mathrm{L}_{\mathrm{B}}$ the ligand 3-piperidino-6-chloropyridazine.

\subsection{Characterization}

Total metal ion concentrations in the biosorption studies were measured using a Varian Spectra AA-400, atomic absorption spectrophotometer (AAS). Elemental chemical analyses were performed by inductively coupled plasma atomic emission spectrometry (ICP-AES) using a Philips ICP PU 7000 Spectrometer on samples previously dissolved by alkaline fusion. $\mathrm{Si}, \mathrm{Al}, \mathrm{Na}$ and $\mathrm{Fe}(\mathrm{III})$ in the solid materials were quantitatively determined after dissolution of known quantities of zeolite material in acid solutions. The method involves the use of lithium metaborate as the fluxing agent, which guarantees thermal stabilization of elements during the fusion stage carried out at $1050^{\circ} \mathrm{C}$. $\mathrm{C}, \mathrm{H}$ and $\mathrm{N}$ analysis were carried out on a Leco CHNS932. The micrographs from scanning electron microscopy (SEM) were obtained in the microscopy laboratory of Minho University (Portugal) using a LEICA Cambridge S360 Scanning Microscope equipped with an EDS system. Before examination, the samples were coated with gold in vacuum to avoid surface charging using a Fisons Intruments SC502 sputter coater. Powder EPR spectra were carried out with a Bruker EMX spectrometer operating at Xband microwave frequencies (ca. 9.5 GHz) at room temperature. Phase analysis was performed by XRD using a Philips PW1710 diffractometer. Scans were taken at room temperature in a $2 \theta$ range between $4^{\circ}$ and $80^{\circ}$, using $\mathrm{Cu}$ $\mathrm{K} \alpha$ radiation. ${ }^{1} \mathrm{H}$ NMR spectra were recorded using a Varian Unity Plus spectrometer at $300 \mathrm{MHz}$, chemical shifts being given in ppm. Room temperature FTIR spectra of pyridazine derivative ligands and solid sample materials were obtained from powdered samples on $\mathrm{KBr}$ pellets, using a Bomem MB104 spectrometer in the range 4000$500 \mathrm{~cm}^{-1}$ by averaging 20 scans at a maximum resolution of $4 \mathrm{~cm}^{-1}$. The electronic UV-vis absorption spectra of pyridazine derivative ligands and residual solutions were collected in the range $600-200 \mathrm{~nm}$ using a Shimadzu UV/ 2501PC spectrophotometer using quartz cells at room temperature. Thermogravimetric analyses of samples were carried out using TGA 50 Shimadzu instrument under high purity helium supplied at a constant $50 \mathrm{~mL} \mathrm{~min}^{-1}$ flow 
rate. All samples were subjected to a $6{ }^{\circ} \mathrm{C} \mathrm{min}{ }^{-1}$ heating rate and were characterized between 25 and $580^{\circ} \mathrm{C}$.

\section{Results and discussion}

\subsection{Biosorption studies}

$\mathrm{Fe}(\mathrm{III})$ ions were efficiently removed from aqueous solutions for a wide range of initial $\mathrm{Fe}$ concentrations tested. The total removal was attained within the first $24 \mathrm{~h}$ of experiment and steady-state equilibrium remained until the end of the experiment (ca. $240 \mathrm{~h}$ ). The biosorption experiments were performed starting from solutions with two different transition metal ions, $\mathrm{Fe}(\mathrm{III})$ and $\mathrm{Cr}(\mathrm{III})$, for comparative purposes, to simulate the competing presence of other metals in real industrial effluents and to assess the specificity of the Fe(III) system.

The results for the variation of $\mathrm{Fe}(\mathrm{III})$ concentration with time in the presence of the bacteria, with and without the zeolite, for different initial concentrations are presented in Fig. 1.
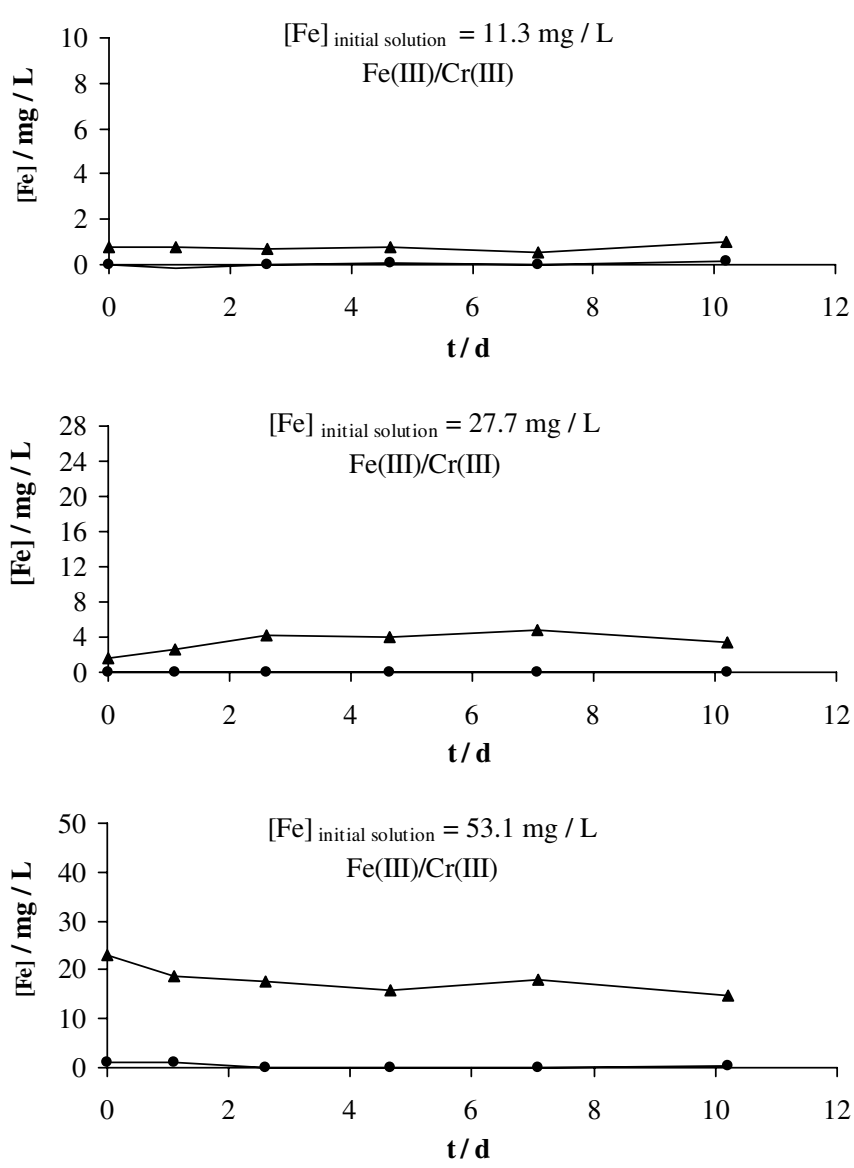

Fig. 1. Variation of $\mathrm{Fe}(\mathrm{III})$ concentration as a function of time in the presence of the bacteria, with $(\boldsymbol{O})$ and without the zeolite $(\boldsymbol{\Delta})$, for different initial concentrations: (a) $C_{\mathrm{Fe}}^{\mathrm{III}}=11.3 \mathrm{mg} / \mathrm{L}$ and $C_{\mathrm{Cr}}^{\mathrm{III}}=9.3 \mathrm{mg} / \mathrm{L}$, (b) $C_{\mathrm{Fe}}^{\mathrm{III}}=27.7 \mathrm{mg} / \mathrm{L}$ and $C_{\mathrm{Cr}}^{\mathrm{III}}=23.7 \mathrm{mg} / \mathrm{L}$ and (c) $C_{\mathrm{Fe}}^{\mathrm{III}}=53.1 \mathrm{mg} / \mathrm{L}$ and $C_{\mathrm{Cr}}^{\mathrm{III}}=51.4 \mathrm{mg} / \mathrm{L}$
Although A. viscosus is not able to retain all the metallic ions, the removal from solution is improved when the biofilm is supported on the zeolite. For the concentrations tested, $\mathrm{Fe}(\mathrm{III})$ removal efficiencies were always higher than $98.5 \%$ and uptake ranged from 1.6 to $7.6 \mathrm{mg} / \mathrm{g}_{\text {zeolite }}$. Lower values for removal efficiencies and for metal uptake were reached for the competing ion, $\mathrm{Cr}$ (III), Fig. 2.

Suspended $A$. viscosus is able to remove $90-60 \%$ of the initial $\mathrm{Fe}$ concentration, depending on this last parameter, suggesting that $\mathrm{Fe}(\mathrm{III})$ is not metabolized by the bacteria, instead, it is probably entrapped by it. Addition of the bacteria suspension is carried out at the end of the exponential growth phase, so $\mathrm{Fe}(\mathrm{III})$ is only retained during the initial stages and the lack of bacteria growth prevents further retention of $\mathrm{Fe}(\mathrm{III})$. Comparison between bacteria in suspension and supported on $\mathrm{NaY}$ zeolite, in terms of $\mathrm{Fe}(\mathrm{III})$ aqueous ion fixation, indicates a better performance from the supported system, which is more obvious as the initial metal concentration increases. The synergetic effect between the support and the bacteria permits the observed
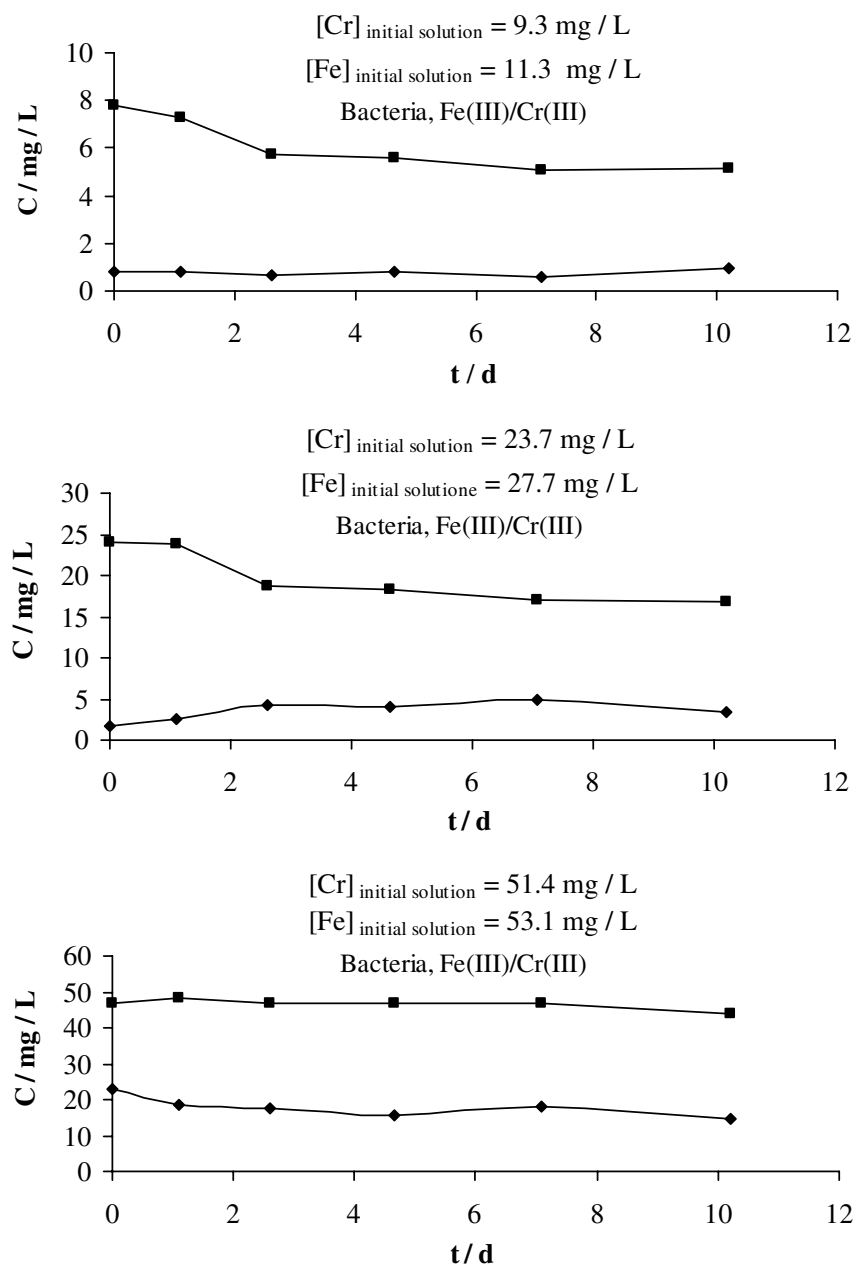

Fig. 2. Variations of $\mathrm{Fe}(\mathrm{III})(\diamond)$ and $\mathrm{Cr}(\mathrm{III})$ ( $\mathbf{\square})$ concentrations as a function of time in the presence of the bacteria, for different initial concentrations: (a) $C_{\mathrm{Fe}}^{\mathrm{III}}=11.3 \mathrm{mg} / \mathrm{L}$ and $C_{\mathrm{Cr}}^{\mathrm{III}}=9.3 \mathrm{mg} / \mathrm{L}, \quad$ (b) $C_{\mathrm{Fe}}^{\mathrm{III}}=27.7 \mathrm{mg} / \mathrm{L}$ and $C_{\mathrm{Cr}}^{\mathrm{III}}=23.7 \mathrm{mg} / \mathrm{L}$ and (c) $C_{\mathrm{Fe}}^{\mathrm{III}}=53.1 \mathrm{mg} / \mathrm{L}$ and $C_{\mathrm{Cr}}^{\mathrm{III}}=51.4 \mathrm{mg} / \mathrm{L}$. 
improvement. It was also observable in Figs. 1 and 2 that there is no release of the entrapped metal ions back into the solution.

$\mathrm{NaY}$ zeolite is a microporous aluminosilicate which has internal supercages with an open diameter of $0.7 \mathrm{~nm}$ and the characteristic dimension of the $A$. viscosus bacterium ranges from 1 to $10 \mu \mathrm{m}$. As a result of these limitations the bacterium is supported on the outer surface of the zeolite. The $A$. viscosus bacterium supported on the $\mathrm{NaY}$ zeolite was analyzed by SEM. The presence of organic materials on the surface of the zeolite confirms that the adhesion of the bacteria is external (Fig. 3a).

Similar studies with chromium(VI) in solution with concentrations ranging from 50.0 to $250.0 \mathrm{mg}_{\mathrm{Cr}} / \mathrm{L}$ were carried out with the same bacterial biofilm, A. viscosus, supported on the FAU zeolites ( $\mathrm{NaY}$ or $\mathrm{NaX}$ ). The improvement of the removal process due to the synergetic effect between biofilm and zeolite was also established. It was shown that the maximum metal removal efficiency is $20 \%$, in both systems, and that the reduction of $\mathrm{Cr}(\mathrm{VI})$ to $\mathrm{Cr}(\mathrm{III})$ is performed by the biofilm itself. These novel catalytic materials show good properties for catalytic oxidation of 1,2-dichlorobenzene in wet air [26].

Samples used in the following procedure were prepared, starting from $\mathrm{Fe}(\mathrm{III})$ aqueous solutions, $100.0 \mathrm{mg}_{\mathrm{Fe}} / \mathrm{L}$, i.e. without the competing effect of other metals.

\subsection{Immobilization of $\mathrm{Fe}$ (III) complexes of pyridazine derivatives}

Both pyridazine derivative ligands were synthesized through a nucleophilic aromatic substitution, from 3,6dichloropyridazine when refluxed with the alkoxide in the corresponding alcohol for the 3-ethoxy-6-chloropyridazine (A) ligand or when refluxed with piperidine in ethanol in the case of the 3-piperidino-6-chloropyridazine (B) ligand (Scheme 1).

In this study, $\mathrm{Fe}$ (III) complexes were immobilized by the flexible ligand method using a large excess of the pyridazine derivative ligands to assure a complete coordination of the $\mathrm{Fe}(\mathrm{III})$ inside the $\mathrm{Y}$ zeolite obtained by the biosorption process $[20,21]$. Two different ligands were used in this study: 3-ethoxy-6-chloropyridazine (A) and 3-piperidino-

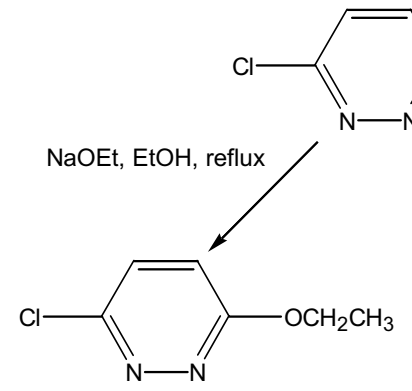

(A)

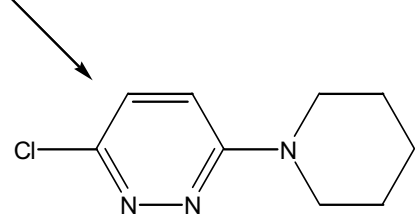

(B)
Piperidine, EtOH, reflux

Scheme 1. Synthesis of pyridazine derivative ligands.

6-chloropyridazine (B). The remaining uncomplexed metal ions in the $\mathrm{Y}$ zeolite were removed by exchange with $\mathrm{NaCl}$ solution and they were monitored by AAS analysis [13]. The brown-orange solid samples were submitted to Soxhlet extraction to remove the residual pyridazine derivative ligands physically adsorbed onto the external surface of the zeolite.

The UV-vis analyses of the residual solutions, obtained before and after Soxhlet extraction, were performed for a further characterization of the prepared materials. The electronic spectrum of the pyridazine derivative ligands exhibits two bands at 217 and $280 \mathrm{~nm}$ for (A) and 220 and $260 \mathrm{~nm}$ for (B) due to $\mathrm{n}-\pi^{*}$ and the highly intense band of $\pi-\pi^{*}$ transitions of the pyridazine group [22].

For both immobilization processes with different pyridazine derivative ligands, before Soxhlet extraction, the presence of ligands in the residual solutions by UV-vis was revealed by the appearance of the band at $\lambda_{\max }=265 \mathrm{~nm}$, thus indicating that the excess of ligand in the initial solutions was removed by filtration. However, in the residual solutions after Soxhlet extraction no electronic bands due to the 3-ethoxy-6-chloropyridazine (A) ligand could be detected in the UV-vis spectra but a small quantity of the 3-piperidino-6-chloropyridazine (B) ligand was detected.

\subsection{Material characterization}

In order to characterize the resulting materials and to assess the efficiency of the immobilization process, the ini-
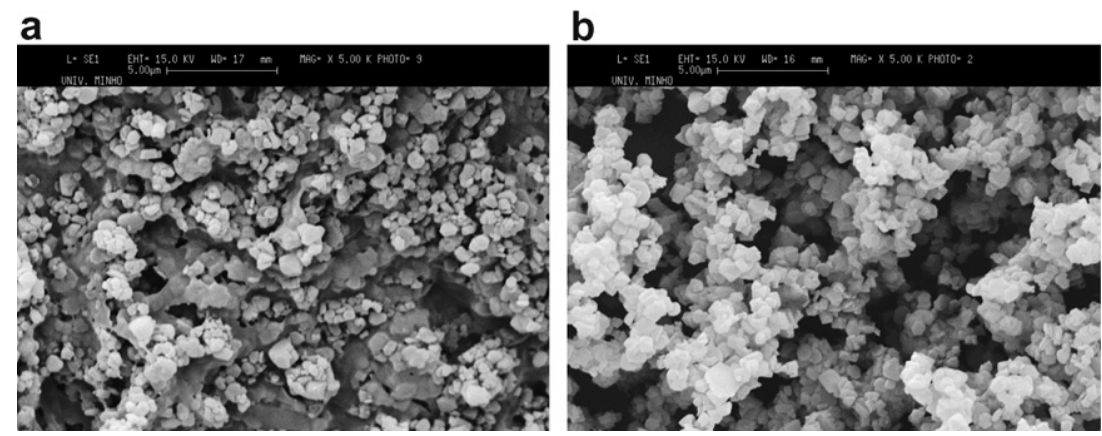

Fig. 3. Scanning electron micrography (SEM) of A. viscosus bacterium supported on the NaY zeolite: (a) before calcination and (b) after calcination. 
tial $\mathrm{NaY}$ zeolite, the $\mathrm{Fe}^{\mathrm{III}}-\mathrm{Y}$ zeolite obtained from the biosorption process, and samples of $\left[\mathrm{Fe}^{\mathrm{III}} \mathrm{L}_{\mathrm{A}}\right]-\mathrm{Y}$ and $\left[\mathrm{Fe}^{\mathrm{III}} \mathrm{L}_{\mathrm{B}}\right]-\mathrm{Y}$ were studied by several techniques and the obtained results were compared.

Structural characterization of the initial $\mathrm{NaY}$ zeolite and of the modified samples was obtained by X-ray diffraction (XRD). The unit cell parameters were calculated from the [533], [642] and [555] reflection peak positions in according to ASTM D 3942-80 method. The framework Si/Al ratio was obtained from the calculated unit cell parameters by using the Breck and Flanigen equation [27]. Bulk Si/Al ratio was determined by inductively coupled plasma emission spectrometry (ICP-AES). The results are reported in Table 1.

The $\mathrm{Si} / \mathrm{Al}$ atomic ratios for all modified zeolites samples did not change substantially after the biosorption and immobilization processes which indicate that no dealumination occurred during these treatments. The bulk and the framework $\mathrm{Si} / \mathrm{Al}$ atomic ratios on $\mathrm{NaY}$ and on modified samples were similar. This indicates that the $\mathrm{Si} / \mathrm{Al}$ atomic ratios were uniformly distributed throughout each zeolite particle and excluded the presence of extra-framework alumina species [28].

These results show that no significant structural changes of the zeolite framework occur (i.e. crystallinity of $\mathrm{NaY}$ is preserved) during the immobilization process and that the zeolite structure is retained upon metal complex encapsulation. Peaks due to the pure Fe(III) complexes were not detected, probably because of their very low percent loading.

It was found that the FTIR patterns of $\left[\mathrm{Fe}^{\mathrm{III}} \mathrm{L}_{n}\right]-\mathrm{Y}$ are very similar and the sample $\left[\mathrm{Fe}^{\mathrm{III}} \mathrm{L}_{\mathrm{B}}\right]-\mathrm{Y}$ has been selected as an example. The infrared spectra over the range of $4000-550 \mathrm{~cm}^{-1}$ of $\mathrm{Na}-\mathrm{Y} \quad(\mathrm{A}), \mathrm{Fe}(\mathrm{III})-\mathrm{Y} \quad$ (B) and $\left[\mathrm{Fe}^{\mathrm{III}} \mathrm{L}_{\mathrm{B}}\right]-\mathrm{Y}$ after Soxhlet extraction $(\mathrm{C})$ are presented in Fig. 4.

Similar to $\left[\mathrm{Cr}^{\mathrm{III}} \mathrm{L}\right]-\mathrm{FAU}$ prepared by flexible ligand method previously reported [20], the spectrum of $\mathrm{NaY}$ shows intense and large bands due to the zeolitic structure: in the region $3700-3300 \mathrm{~cm}^{-1}$ assigned to the surface hydroxyl groups and bands corresponding to the lattice vibrations are observed in the spectral region between $1300-450 \mathrm{~cm}^{-1}$ [29].

Different assays were carried out to confirm the absence of the A. viscosus bacterium in the immobilization process. The NaY was mixed under identical experimental condi-

Table 1

Structural and chemical analysis of $\left[\mathrm{Fe}^{\mathrm{III}} \mathrm{L}_{n}\right]-\mathrm{Y}$ zeolite samples

\begin{tabular}{llll}
\hline & $a_{\mathrm{o}}{ }^{\mathrm{a}}$ & $\mathrm{Si} / \mathrm{Al}^{\mathrm{b}}$ & $\mathrm{Si} / \mathrm{Al}^{\mathrm{c}}$ \\
\hline $\mathrm{NaY}$ & 24.63 & 2.80 & 2.88 \\
$\mathrm{Fe}^{\mathrm{III}}-\mathrm{Y}$ & 24.64 & 2.70 & 2.75 \\
{$\left[\mathrm{Fe}^{\mathrm{III}} \mathrm{L}_{\mathrm{A}}\right]-\mathrm{Y}$} & 24.63 & 2.81 & 2.89 \\
{$\left[\mathrm{Fe}^{\mathrm{III}} \mathrm{L}_{\mathrm{B}}\right]-\mathrm{Y}$} & 24.64 & 2.74 & 2.77 \\
\hline
\end{tabular}

${ }^{\mathrm{a}} a_{\mathrm{o}}$ is the unit cell parameter determined from XRD analysis.

b $\mathrm{Si} / \mathrm{Al}$ framework ratio determined from XRD analysis.

${ }^{c} \mathrm{Si} / \mathrm{Al}$ bulk ratio determined from ICP-AES analysis.

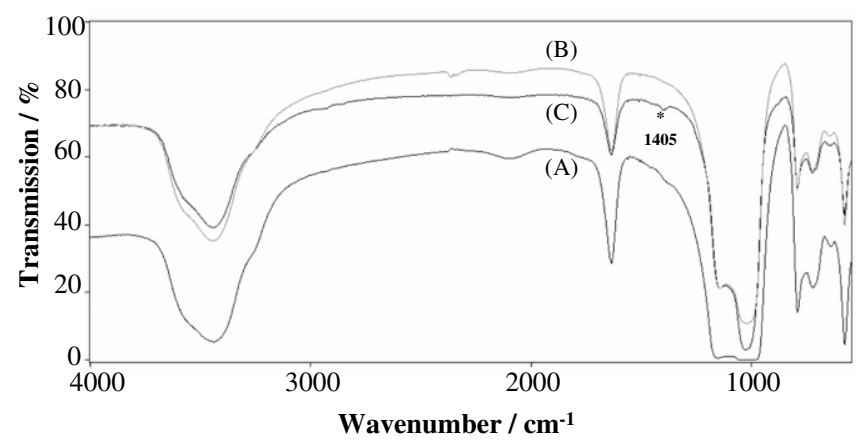

Fig. 4. FTIR spectra in the range $550-4000 \mathrm{~cm}^{-1}$ of (A) $\mathrm{NaY}$, (B) $\mathrm{Fe}^{\mathrm{III}}-\mathrm{Y}$ and $(\mathrm{C})\left[\mathrm{Fe}^{\mathrm{III}} \mathrm{L}_{\mathrm{B}}\right] \mathrm{Y}$.

tions with $15 \mathrm{~mL}$ of $A$. viscosus culture media and subsequently analyzed by FTIR [26]. Before and after calcination, the sample $\mathrm{Fe}^{\mathrm{III}}-\mathrm{Y}$ was controlled by FTIR and chemical analysis.

The FTIR spectrum of the A. viscosus bacterium is typical of bacterial extracellular polymeric substances with a complex mixture of macromolecular polyelectrolytes including polysaccharides, proteins, nucleic acids [30] and lipids or humic substances [31]. In the FTIR spectrum of $\mathrm{NaY}$ with $A$. viscosus[26], the presence of the organic material can be only detected in the region $2980-2800 \mathrm{~cm}^{-1}$ and $1580-1250 \mathrm{~cm}^{-1}$ where the zeolite does not absorb, by small bands located at 2970,2925 and $2860 \mathrm{~cm}^{-1}$ attributed to $\mathrm{C}-\mathrm{H}$ stretching of the groups $\mathrm{CH}_{2}$ and $\mathrm{CH}_{3}$, and at 1457 and $1400 \mathrm{~cm}^{-1}$ due to vibrations of the carboxylate and amine groups [30-34].

In addition to the strong bands caused by the initial zeolite, the FTIR spectrum of the $\mathrm{Fe}^{\mathrm{III}}-\mathrm{Y}$ before calcination exhibits a band at $1400 \mathrm{~cm}^{-1}$ attributed to the presence of organic matter from the A. viscosus bacterium [20]. After calcination, (Fig. 4 - spectrum (B)) the absence of the bands in the region $2970-2800 \mathrm{~cm}^{-1}$ and of the band at $1400 \mathrm{~cm}^{-1}$ is evidence for the previous presence of the $A$. viscosus bacterium. The presence of the $\left[\mathrm{Fe}^{\mathrm{III}} \mathrm{L}_{\mathrm{B}}\right]$ complex (Fig. 4 - spectrum (C)) can be only detected in the range $1580-1250 \mathrm{~cm}^{-1}$ where the zeolite does not absorb, by small broad bands at $1405 \mathrm{~cm}^{-1}$. This band is probably due to the dialkylamino group of 3-piperidino-6-chloropyridazine ligand.

No shift or broadening of the $\mathrm{Y}$ zeolite vibrations are observed after iron biosorption and upon inclusion of the complexes, which provides further evidence that the framework zeolite remains unchanged in agreement with XRD results.

The success of the heat treatment of the $\mathrm{Fe}^{\mathrm{III}}-\mathrm{Y}$, used to burn off the organic matter, was confirmed by the analytical data of carbon and nitrogen content obtained by elemental analysis. As expected, the presence of carbon and nitrogen was not detected in this sample. Nevertheless, analysis of SEM micrographs after calcinations shows the absence of the organic material on the zeolite (Fig. 3b). 
The chemical analyses carried out on the solid samples, are included in Table 2, where it can be observed that the loading of $\mathrm{Fe}(\mathrm{III})$ is two metal ions per unit cell after the biosorption process.

The immobilization of $\mathrm{Fe}(\mathrm{III})$ complexes of pyridazine derivatives in $\mathrm{Y}$ zeolite produces a slight leaching of $\mathrm{Fe}(\mathrm{III})$, more evident for the $\left[\mathrm{Fe}^{\mathrm{III}} \mathrm{L}_{\mathrm{A}}\right]-\mathrm{Y}$ sample. It can also be calculated that the $\left(\mathrm{AlO}_{4}\right)^{-}$charges in the modified samples are not fully compensated by $\mathrm{Fe}^{3+}$ and $\mathrm{Na}^{+}$ions. Most likely protons came from the co-exchange between $\mathrm{Na}^{+}$ions from zeolite and the residual protons present in solutions of pyridazine derivative ligands. Charge compensation by co-exchange of protons leads to some residual acidity in the zeolite. This residual acidity could have an effect on the catalytic behavior of the samples [35].

Powder EPR spectra recorded at room temperature for all $\mathrm{Fe}-\mathrm{Y}$ samples are represented in Fig. 5. It was shown that these spectra are typical of magnetically diluted samples dominated by high-spin $\mathrm{Fe}(\mathrm{III})$ contributions $\left(\mathrm{d}^{5}\right.$, $\mathrm{S}=5 / 2$ ) [36] which implies that the Fe(III) complexes are dispersed within the zeolite supercages, acting as a diamagnetic matrix.

The EPR spectrum of $\mathrm{Fe}^{\mathrm{III}}-\mathrm{Y}$ presented two types of $\mathrm{Fe}$ (III) signals at $g=4.3$, originated from the middle Kramers doublet and a broad signal at $g=2.3$ (Fig. 4a). The first signal corresponds to some rhombic $\mathrm{Fe}(\mathrm{III})$ located in the framework zeolite [36,37]. The broad signal at $g=2.3$ corresponds to some nearly tetrahedral or octahe-

Table 2

Elemental chemical analysis of $\left[\mathrm{Fe}^{\mathrm{III}} \mathrm{L}_{n}\right]-\mathrm{Y}$ zeolite samples

\begin{tabular}{lllllll}
\hline & \multicolumn{6}{l}{ Elemental analysis $(\%)$} \\
\cline { 2 - 7 } & $\mathrm{Si} / \mathrm{Al}$ & $\mathrm{Fe}^{\mathrm{IIIa}}$ & $\mathrm{Fe}^{\mathrm{IIIb}}$ & $\mathrm{C}$ & $\mathrm{H}$ & $\mathrm{N}$ \\
\hline $\mathrm{NaY}$ & 2.80 & - & - & - & - & - \\
$\mathrm{Fe}^{\mathrm{III}}-\mathrm{Y}$ & 2.80 & 0.57 & 1.96 & - & - & - \\
{$\left[\mathrm{Fe}^{\mathrm{III}} \mathrm{L}_{\mathrm{A}}\right]-\mathrm{Y}$} & 2.79 & 0.68 & 1.62 & 0.65 & 2.82 & 0.22 \\
{$\left[\mathrm{Fe}^{\mathrm{II}} \mathrm{L}_{\mathrm{B}}\right]-\mathrm{Y}$} & 2.77 & 0.55 & 1.88 & 0.74 & 2.93 & 0.27 \\
\hline
\end{tabular}

${ }^{\mathrm{a}} \mathrm{Fe}(\mathrm{III})$ loading on NaY determined from ICP-AES analysis.

${ }^{\mathrm{b}} \mathrm{Fe}(\mathrm{III})$ loading on NaY per unit cell (UC).

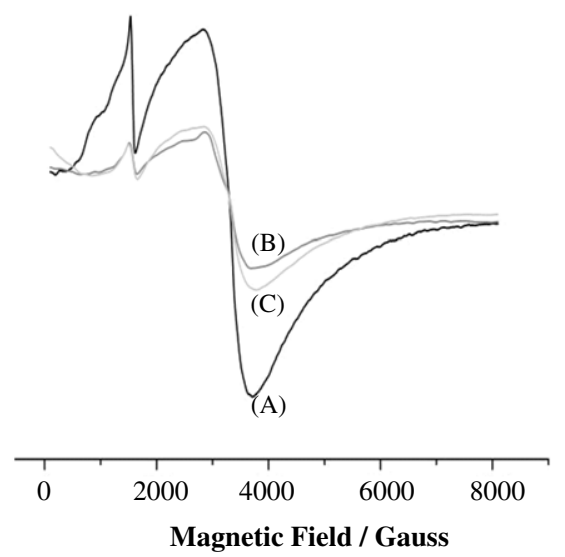

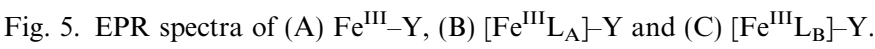

dral Fe(III) ions in the crystalline field [38]. The commonly accepted assignment for these signals has been described in detail elsewhere [36-39]. The first type of iron ions probably originates from dimmer iron in the framework zeolite. The board signal is difficult to attribute because it resembles dipolar couplings [37].

The EPR spectra for the Fe(III) pyridazine derivative complexes inside the zeolite are similar to $\mathrm{Fe}^{\mathrm{III}}-\mathrm{Y}$ spectra. In both complexes spectra with the same signals of $\mathrm{Fe}(\mathrm{III})$ at $g=4.3$ and $g=2.3$ are observed, with different magnetic susceptibility measurements. These differences are related to $\mathrm{Fe}$ (III) framework zeolite coordinated with the pyridazine derivative ligands or $\mathrm{Fe}(\mathrm{III})$ complexes in supercages of the zeolite [39-41].

When taken together, the spectroscopic information combined with analytical data clearly prove that $\mathrm{Fe}(\mathrm{III})$ complexes of pyridazine derivatives have been assembled inside the zeolite. M/ligand (1:1) stoichiometry was found from analytical data (Table 2). However, a fraction of uncomplexed $\mathrm{Fe}^{3+}$ was observed. The fact that this fraction could still be present at certain sites of the zeolite cannot ruled be out. The Y zeolite has two sites inside the hexagonal prism and sodalite cages where cations can be accommodated and solvated by the zeolite oxygen atoms, but they cannot participate in the formation of the Fe(III) complexes due to steric constraints [42]. Only those $\mathrm{Fe}^{3+}$ located inside the supercages are available to interact with pyridazine derivative ligands, forming the complex $[42,43]$. The migration of some $\mathrm{Fe}^{3+}$ from the supercages to the sodalite cages probably is due to the process of calcination after biosorption [44].

Immobilization of $\mathrm{Fe}(\mathrm{III})$ complexes in the $\mathrm{Y}$ zeolite was further supported by its thermogravimetric analysis (TGA). As the TGA curves of $\left[\mathrm{Fe}^{\mathrm{III}} \mathrm{L}_{n}\right]-\mathrm{Y}$ are very similar the sample $\left[\mathrm{Fe}^{\mathrm{III}} \mathrm{L}_{\mathrm{B}}\right]-\mathrm{Y}$ has been chosen as an example. Fig. 6 shows the TGA curves with weight loss derivative behavior of the $\mathrm{Fe}^{\mathrm{III}}-\mathrm{Y}$ and $\left[\mathrm{Fe}^{\mathrm{III}} \mathrm{L}_{\mathrm{B}}\right]-\mathrm{Y}$.

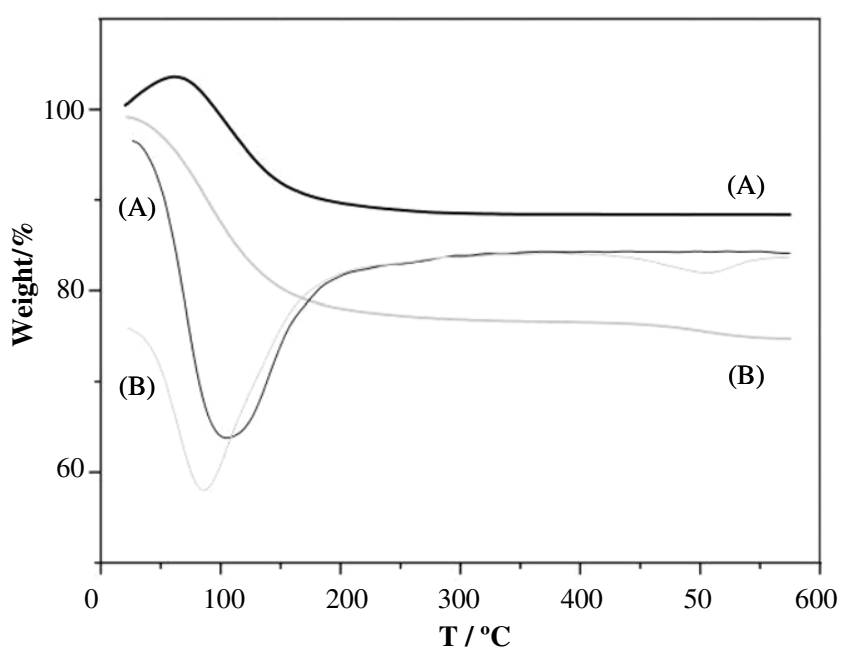

Fig. 6. TG (-) and DTG (-) curves for $\mathrm{Fe}^{\mathrm{III}}-\mathrm{Y}(\mathrm{A})$ and $\left[\mathrm{Fe}^{\mathrm{III}} \mathrm{L}_{\mathrm{B}}\right]-\mathrm{Y}(\mathrm{B})$. 
Table 3

Results of thermogravimetric analysis of $\left[\mathrm{Fe}{ }^{\mathrm{III}} \mathrm{L}_{n}\right]-\mathrm{Y}$ zeolite samples

\begin{tabular}{llll}
\hline & $T_{1}{ }^{\mathrm{a}}\left({ }^{\circ} \mathrm{C}\right)$ & $T_{2}{ }^{\mathrm{b}}\left({ }^{\circ} \mathrm{C}\right)$ & Weight $\operatorname{loss}^{\mathrm{c}}(\%)$ \\
\hline $\mathrm{NaY}$ & 110 & - & - \\
{$\left[\mathrm{Fe}^{\mathrm{III}} \mathrm{L}_{\mathrm{A}}\right]-\mathrm{Y}$} & $80-110$ & 510 & 1.3 \\
{$\left[\mathrm{Fe}^{\mathrm{III}} \mathrm{L}_{\mathrm{B}}\right]-\mathrm{Y}$} & $80-110$ & 510 & 1.6 \\
\hline
\end{tabular}

a Temperature of water desorption obtained from DTG curve.

b Temperature of complexes decomposition obtained from DTG curve.

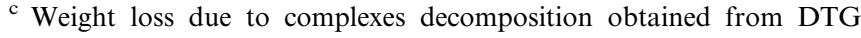
curve.

The TGA curve of $\mathrm{Fe}^{\mathrm{III}}-\mathrm{Y}$ zeolite shows a weight loss at $110^{\circ} \mathrm{C}$ which can be attributed to the removal of intra-zeolite water. After the immobilization of Fe(III) complexes in $\mathrm{Y}$ zeolite, two major stages of weight loss occur in the broad temperature range (i.e. $110-580^{\circ} \mathrm{C}$ ). The first stage occurs above $110^{\circ} \mathrm{C}$ with comparable weight loss with the $\left[\mathrm{Fe}^{\mathrm{III}} \mathrm{L}_{n}\right]-\mathrm{Y}$ samples and this is probably due to intrazeolite water desorption and to desorption of water associated with the immobilized Fe(III) complexes. However, the decomposition of the immobilized complex occurs in the second stage of TGA curve, which starts at range 400$580^{\circ} \mathrm{C}$. The differences were observed in the second stage of TGA curve for the weight losses, which correspond to the decomposition of the pyridazine derivatives $\mathrm{Fe}(\mathrm{III})$ complexes immobilized in $\mathrm{Y}$ zeolite (Table 3).

A very small weight loss due to complex decomposition is probably related to: (i) the presence of a small amount of metal complex in the supercages of the zeolite and (ii) the iron(III) framework zeolite coordinated with pyridazine derivative ligands.

\section{Conclusions}

The immobilization of $\mathrm{Fe}(\mathrm{III})$ complexes of pyridazine derivatives in $\mathrm{Y}$ zeolite has been studied by means of combined biosorption studies with heterogenization of transition metal complexes in zeolites. The immobilization was carried out by free diffusion of the ligands through the zeolite pores exchanged with $\mathrm{Fe}$ (III) metal ion, obtained by the biosorption process. A biofilm of $A$. viscosus supported on $\mathrm{Y}$ zeolite is able to remove low concentrations of iron from aqueous solutions and can be applied to a wide variety of other transition metals present in wastewater remediation. The Fe(III) is exchanged in the zeolite and coordinated with pyridazine derivative ligands.

By combining surface analysis and spectroscopic data it was possible to confirm that the $\mathrm{Fe}$ (III) complexes of pyridazine derivatives can be immobilized in the $\mathrm{Y}$ supercages zeolite, without damage to the original matrix or loss of its crystallinity. The EPR spectra of the $\mathrm{Fe}(\mathrm{III})$ complexes in Y zeolite show the signals at $g=4.3$ and 2.3, attributed to $\mathrm{Fe}(\mathrm{III})$ species coordinated to pyridazine derivative ligands with different magnetic susceptibility measure- ments.

Finally, the strategy for the immobilization of iron complexes can be extended to other transition metals complexes with known catalytic properties in micro- and mesoporous structures. These materials have potential applications in heterogeneous catalysis under mild conditions specifically for oxidation reactions.

\section{Acknowledgments}

Dr. C.L. Remesar (GIQIMO, Santiago de Compostela University, Spain) is gratefully acknowledged for performing and analyzing the EPR measurements. We thank Dr. A.S. Azevedo for collecting the powder diffraction data and Dr. C. Ribeiro, from the Department of Earth Sciences of the University of Minho, for chemical analysis. This work was supported by the FCT (Portugal) through POCTI and FEDER projects (ref: POCTI/44840/QUI/2002 and POCTI-SFA-3-686).

\section{References}

[1] S.E. Bailey, T.J. Olin, R.M. Bricka, D.D. Adrian, Water Res. 33 (11) (1999) 2469-2479.

[2] Y. Sag, T. Kutsal, Chem. Eng. J. 60 (1995) 181-188.

[3] R.A. Van Santen, G.J. Kramer, Chem. Rev. 95 (1995) 637-660.

[4] J.R. Duncan, D. Brady, A. Stoll, Environ. Technol. 15 (1994) 429 438.

[5] G.M. Woodburn, Q. Yu, J.T. Matheickal, Water Res. 33 (2) (1999) 335-342.

[6] C. Quintelas, T. Tavares, Biotechnol. Lett. 23 (2001) 1349-1353.

[7] P.P. Knops-Gerrits, D.E. DeVos, F. Thibault-Starzyk, P.A. Jacobs, Nature 369 (1994) 543-546.

[8] D.E. DeVos, P.P. Knops-Gerrits, R.F. Parton, B.M. Weckhuysen, P.A. Jacobs, R.A. Schoonheydt, J. Inclus. Phenom. Mol. Recog. Chem. 21 (1995) 185-213.

[9] D.E. DeVos, M. Dams, B.F. Sels, P.A. Jacobs, Chem. Rev. 102 (2002) 3615-3640.

[10] D.E. DeVos, I.F.K. Vankelecom, P.A. Jacobs (Eds.), Chiral Catalyst Immobilization and Recycling, John Wiley and Sons, Weinheim, 2000 .

[11] A. Corma, H. Garcia, Eur. J. Inorg. Chem. (2004) 1143-1164.

[12] A. Fuerte, M. Iglesias, F. Sanchez, A. Corma, J. Mol. Catal. A: Chem. 21 (2004) 227-235.

[13] N. Nunes, R. Amaro, F. Costa, E. Rombi, M.A. Carvalho, I.C. Neves, A.M. Fonseca, Eur. J. Inorg. Chem. (2007) 1682-1689.

[14] F. Costa, C.J.R. Silva, M.M.M. Raposo, A.M. Fonseca, I.C. Neves, A.P. Carvalho, J. Pires, Micropor. Mesopor. Mater. 72 (2004) 111 118 .

[15] V. Ramaswamy, M.S. Kirshan, A.V. Ramaswamy, J. Mol. Catal. A: Chem. 181 (2002) 81-89.

[16] C. Simons, U. Hanefeld, I.W.C.E. Arends, R.A. Sheldon, T. Maschmeyer, Chem. Eur. J. 10 (2004) 5829-5835.

[17] R. Augustine, S. Tanielyan, S. Anderson, H. Yang, Chem. Commun. (1999) 1257-1258.

[18] H.H. Wagner, H. Hausmann, W.F. Holderich, J. Catal. 203 (2001) $150-156$.

[19] M. Costas, K. Chen, L. Que Jr., Coord. Chem. Rev. 200-202 (2000) 517-544.

[20] H. Figueiredo, M.M.M. Raposo, A.M. Fonseca, I.C. Neves, C. Quintelas, T. Tavares, in: J. Cejka, N. Zilková, P. Nachtigall (Eds.), Studies in Surface Science and Catalysis, vol. 158, Elsevier, Amsterdam, The Netherlands, 2005, pp. 1073-1080.

[21] M.R. Maurya, S.J.J. Titinchi, S. Chand, J. Mol. Catal. A: Chem. 24 (2) (2004) 257-264.

[22] W.J. Coates, in: A.R. Katritzky, C.W. Rees, E.F.V. Scriven (Eds.), Comprehensive Heterocyclic Chemistry II, vol. 6, Pergamon Press, Oxford, 1996, pp. 1-91. 
[23] F.J.R. Salguero, J.M. Lehn, Tetrahedron Lett. 40 (1999) 859-862.

[24] N.-D. Sung, K.-S. Yun, T.-Y. Kim, K.-Y. Choi, M. Suh, J.-G. Kim, Il.-H. Suh, J. Chin, Inorg. Chem. Commun. 4 (2001) 377-380.

[25] S. Brooker, Eur. J. Inorg. Chem. 10 (2002) 2535-2547, and references cited therein.

[26] H. Figueiredo, I.C. Neves, C. Quintelas, T. Tavares, M. Taralunga, J. Mijoin, P. Magnoux, Appl. Catal. B: Environ. 66 (3-4) (2006) 274 280.

[27] D.W. Breck, E.M. Flanigen, Molecular Sieves, Society of Chemical Industry, London, 1968, p. 47.

[28] K. Sato, Y. Nishimura, N. Matsubayashi, M. Imamura, H. Shimada, Micropor. Mesopor. Mater. 59 (2-3) (2003) 133-146.

[29] B. Imelik, J.V. Vedrine (Eds.), Catalyst Characterization, Plenum Press, New York, 1994.

[30] A. Omoike, J. Chorover, Biomacromolecules 5 (2004) 1219-1230.

[31] M.H. Zandvoort, P.N.L. Lens, E. Van Hullebusch, Soil Sediment Contam. 12 (5) (2003) 679-680.

[32] W. Zeroual, C. Choisy, S.M. Doglia, H. Bobichon, J.F. Angiboust, M. Manfait, Biochim. Biophys. Acta 1222 (1999) 171-178.

[33] D. Helm, D. Naumann, FEMS Microbiol. Lett. 126 (1995) 75-80.
[34] J. Smith, H. Flemming, Int. Biodeter. Biodegr. 41 (1) (1998) 1-11.

[35] B.M. Weckhuysen, H. Leeman, R.A. Schoonheydt, Phys. Chem. Chem. Phys. 1 (1999) 2875-2880.

[36] K. Flogeac, E. Guillon, M. Aplincourt, J. Colloid Interf. Sci. 286 (2005) 596-601.

[37] D. Goldfarb, M. Bernardo, K.G. Strohmaier, D.E.W. Vaughan, H. Thomann, J. Am. Chem. Soc. 116 (1994) 6344-6353.

[38] E.A. Zhilinskaya, G. Delahay, M. Mauvezin, B. Coq, A. Aboukais, Langmuir 19 (2003) 3596-3602.

[39] P. Ratnasamy, R. Kumar, Catal. Today 9 (1991) 329-416.

[40] A.K. Boudalis, Y. Sanakis, C.P. Raptopoulou, A. Terziz, J.P. Tuchagues, S.P. Perlepes, Polyhedron 24 (2005) 1540-1548.

[41] S.L. Jain, P. Bhattacharyya, J. Chem. Soc., Dalton Trans. (2005) 2696-2701.

[42] M. Alvaro, B. Ferrer, H. Garcia, A. Sanjuan, Tetrahedron 55 (1999) 11895-11902.

[43] N. Xiao, Q. Xu, J. Sun, J. Chen, J. Chem. Soc., Dalton Trans. (2006) 603-608.

[44] S.J. Kulkarni, S.B. Kulkarni, Thermochim. Acta 56 (1) (1982) 93107. 